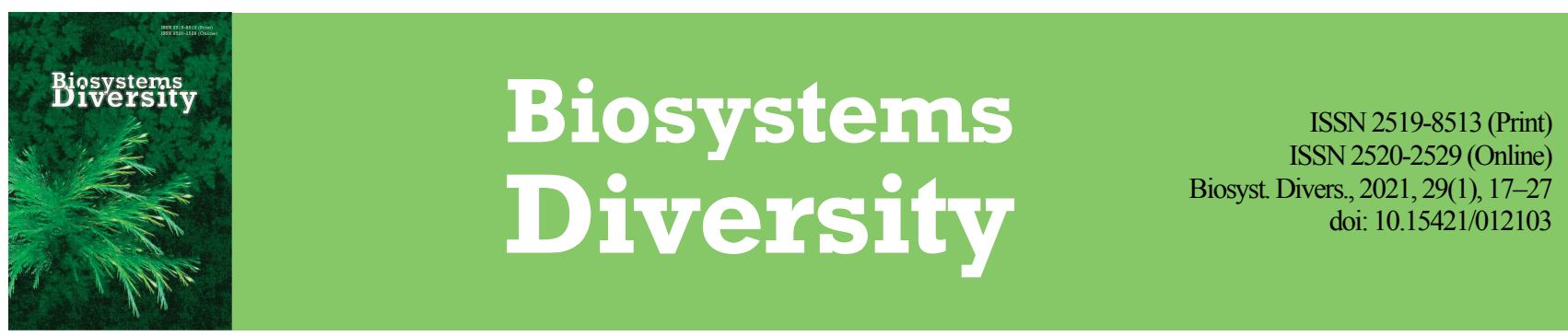

\title{
Geographical distribution, habitats and modern state of Carlina cirsioides (Asteraceae) populations
}

\author{
V. I. Melnyk*, I. O. Kovalchuk**, L. I. Dovhopola***, Y. P. Shapran*** \\ * M. M. Gryshko National Botanical Garden of the National Academy of Sciences of Ukraine, Kyiv, Ukraine \\ **Kremenets Botanical Garden, Kremenets, Ukraine \\ ***Hryhorii Skovoroda University in Pereiaslav, Pereiaslav, Ukraine
}

Article info

Received 28.01.2021

Received in revised form 02.03.2021 Accepted 05.03.2021

M. M. Gryshko National Botanical Garden of the National Academy

of Sciences of Ukraine, Timiryazevska

st. 1, Kyiv, 01014, Ukraine.

Tel.: + 38-050-995-20-52.

E-mail:melnykviktor6@gmail.com

Kremenets Botanical Garden

Botanical st., 5, Kremenets, 47003,

Ukraine Tel: + 38-093-546-21-54

E-mail:kbs1G@ukr.net

Hryhorii Skovoroda University

in Pereiaslav, Sukhomlynskyst., 30,

Pereiaslav, 08401, Ukraine.

$\mathrm{Tel}:+38-093-665-62-51$

E-mail:bogysh@ukr.net
Melnyk, V. I., Kovalchuk, I. O., Dovhopola, L. I., \& Shapran, Y. P. (2021). Geographical distribution, habitats and modern state of Carlina cirsioides (Asteraceae) populations. Biosystems Diversity, 29(1), 17-27. doi:10.15421/012103

The study of the current state and habitats of rare and threatened species of plants is a relevant task of ecological research. The paper presents the results of the study of systematic position, habitats and modern state of populations of a rare species included in the Red DataBook of Ukraine Carlina cirsioides Klokov ( $=$ C. acaulis L.). Carlina cirsioides is well-known to European phytosozologists as an endemic and relic species of the Flora of Ukraine. At the same time, the species independence of this taxon is not recognized by the authors of monographs on the Carlina genus and by the authors of "Flora Europaea". Comparative morphological, chorological and ecological-coenotic analyses do not give sufficient reasons to consider $C$. cirsioides described by Klokov as a separate species, endemic and relic species of the Flora of Ukraine. According to the morphological traits, the specimens from the lowland part of Ukraine belong to the $C$. acaulis caulescens subspecies, which is distributed mostly in the lowlaand regions of Europe. Ecological-coenotic conditions of habitats of $C$. acaulis in the plains of Ukraine are different from those in the mountain regions and are close to the plains habitats of this species in Central Europe. Steppe communities of class FestucoBrometea, of which C. acaulis is component in the plains part of Ukraine, are close to xerothermic herbaceous communities of Central Europe; forest communities of Erico-Pinetea with C. cirsioides in Ukrainian Polissia and the North-East Poland are very close by floristic composition. The removal of separate species status of the plains populations of $C$. acaulis near the eastern border of the range does not at all downplay its sozological significance. Taking into account the low number of $C$. acaulis in the Volhynian-Podolian Upland and in the Polesian Lowland, all localities of this species in the lowland part of the range in Ukraine must be taken under protection in situ.

Keywords: rare species; flora; systematic position; range; communities; protection.

\section{Introduction}

Development of the scientific basis of the protection of floristic diversity is a relevant task of ecological surveys at the current stage. Special attention should be drawn to rare and threatened species of plants of the natural flonas. Providing protection to them is possible based on integrated in detail studies of geographic distribution, habitats and modern state of populations. In the conditions of intense anthropogenic pressure on the ecosystems, an urgent task, according to the Global Strategy of Plant Conservation (Heywood, 2009; Diekson, 2013), is monitoring the state of populations of endemic, relic and rare species, the ranges of which are represented by low number of small populations (Falk \& Holsinger, 1991; Brigham \& Schwartz, 2003; Berg et al., 2014; Corlett, 2016; Volis, 2016). Special attention in phytosozological aspect should be paid to the studies of spatial and age structures of populations of rare and extinct species of natural floras (Bowman et al., 2010; Quinones-Perez et al., 2014; Corlett, 2016; Volis, 2016).

An effective method of protection of floristic diversity is conservation of rare exceptional species within genera complexes. The genus Carlina L. (Asteraceae) is rich in rare species, including 28 species distributed in the Holarctic kingdom (Europe, North Africa, Siberia) from the Azores and Canary Islands to North-West China (Meusel \& Kästner, 1994; Wahrmund et al., 2010). The flora of Europe includes 13 species of the Carlina genus (Webb, 1976), and the flora of Ukraine contains 5 species: C. acaulis L., C. biebersteinii Bernh. ex Hornem., C. vulgaris L., C. onopordifolia Besser ex Szafer, Kulcz. \& Pawl. (=C. acanthifolia All.), C. cirsioides Klokov (Klokov, 1962). The two latter species are rare, in- cluded in the Red Data Book of Ukraine (Didukh et al., 2009). Furthermore, $C$. onopordifolia is included in the IUCN Red List (Melnyk, 2011) and $C$. cirsioides is assigned to the European Red List of Globally Threatened Animals and Plants (European ..., 1991). Despite its high phytosozological status, Carlina cirsioides is not sufficiently studied in the systematic, chorological and ecological-coenotic aspects.

Furthermore, the systematic position of $C$. cirsioides is a subject of discussions. Klokov (1954), who described this species, identified it to endemics and relics of the Flora of Ukraine. Because this species is included to the European Red List (European ..., 1991), it is one of the most wellknown endemic of Ukrainian flora in the European Scientific Community. At the same time, neither the authors of Flora Europaea (Webb, 1976) nor the authors of the monograph on the Carlina genus (Meusel \& Kästner, 1994) have even mentioned this species in their data. To solve this contradiction, a comparative study of morphology, chorology, habitats of $C$. cirsioides together with the closely related species $C$. acaulis was needed.

The objective of our investigation was determination of the systematic position, patterns of distribution, habitats and modern state of populations of $C$. cirsioides based on comparative-morphological, geographic and ecological-coenotic study.

\section{Materials and methods}

The study was based on the materials of field surveys performed in 2010-2020. Population of $C$. cirsioides was surveyed in the plains of Ukraine in Rivne, Zhytomyr, Lviv, Ivano-Frankivsk, Ternopil and Khmel- 
nytskyj regions. We studied herbarium samples of $C$. cirsioides kept in the herbariums of the M. G. Kholodny Institute of Botany of the National Academy of Sciences of Ukraine (KW), M. M. Gryshko National Botanical Garden (KWHA), Taras Shevchenko National University of Kyiv (KWU), Ivan Franko National University of Lviv (LW), National Museum of Natural History of the National Academy of Sciences of Ukraine (NAS) in Lviv (LWS), Institute of Ecology of Carpathians of the NAS of Ukraine (LWKS), and Rivne Regional Museum of Local Lore. Schematic range maps for the species were developed using the point method of cartographic image. For determination of ontogenetic spectrums of populations of $C$. cirsioides, we used diagnostic traits of the stages of the ontogenesis of the species described by Zelenchuk (1987). The account of density of the populations was made on $1 \mathrm{~m}^{2}$ wide transects, within which $1 \mathrm{x} 1 \mathrm{~m}^{2}$ experimental plots were arranged.

\section{Results}

Georgaphic distribution of C. cisrsioides in Ukraine. Polesian Lowland Volhynian Polissa

Rivne region

1) Kostopil district, outskirts of Derazhne village (Antonova, 1989, Rivne Regional Museum of Local Lore);

2) Rivne district, Oleksandriiske Forestry (Antonova, 1991, Rivne Regional Museum of Local Lore);

3) Rivne district, Liubomyrske Forestry (Melnyk, 2002, KWHA).

Zhytomyr region

4) Zhytomyr, Sokolova Hora (Klokov, 1962);

5) Pulyny district, Zelena Dibrova village (Klokov, 1962);

6) Romaniv district, Yasnohorod village (Klokov, 1962);

7) Berdychiv district, Katerynivka village, the Ahativka Tract (Khakevych, 1947, KW).

Kyiv Polissa

Kyiv region

8) outskirts of Kyiv, Bilychi (Rakochi 1901, LE, Vavrysh, Dubovyk,

1972, KW);

9) Brovary (Shmalhausen, 1886, KW);

$\mathrm{KW})$.

10) Brovary district, Litky Forestry, Zalissia (Selezhynskyj, 1904,

Volhynian Upland

Rivne region

11) Hoshcha district, outskirts of Richyshche village (Zozniuk, Antonova, 1991, Rivne Regional Museum of Local Lore);

12) Zdolbuniv district, outskirts of Bohdashiv (LE);

13) Zdolbuniv district, outskirts of villages Keraievychi-Orkiv near Rivne (Panek, 1925, Volhynian Museum of Local Lore in Lutzk).

The Podolian Upland

Lviv region

14) Zolochiv district, Chervone village, Lysa Hora mountain (Motyka, 1947; Buhalo, 1955, LW; Panchyshyna, 1960, LW; Sheliah-Sosonko, Kukovytsia, 1968, KW; Zelenchuk, 1981, LW; Kahalo, 1983, LW; Zelenchuk, 1985, LW; Zaveruha, 1986, KW; Zahulsky, 1988, LW);

15) Zolochiv district, outskirts of Chervone village, the Sypuha mountain (Buhalo, 1955, LW);

16) Zolochiv district, Stinka village, Holohirka Tract (Zaveruha, KW, 1961; Skoroplias, Batochenko, KWHA, 2012);

17) Zolochiv district, outskirts of Zarvanytsia village, Zarvanytsia mountain (Skoroplias, Batochenko, KWHA, 2013);

18) Zolochiv district, Holohory village (Melnyk, 1957, KW);

19) Zolochiv district, outskirts of Trudovach village (Motyka, 1947);

20) Brody district, the Makitra mountain in the outskirts of Buchyno village (Motyka, 1947; Melnyk \& Parubok, 2004);

21) Zolochiv district, Pluhiv village (Melnyk, 2013, KWHA);

Ivano-Frankivsk region

22) Rohatyn district., Chortova mountain between villages Pukiv and Babyntsi (Didukh, Sheliah-Sosonko, 1977, KW; Shumilova, 1981, KW; Kahalo, 1987, LW; Melnyk \& Parubok, 2004; Dmytrash \& Shumska, 2011; Skoroplias, KWHA, 2012);

23) Rohatyn district, outskirts of Pukiv village, the mountain Chorna (Kukovytsia \& Sheliah-Sosonko, 1968, KW).
24) Rohatyn district, north-east outskirts of Malynivka village, the Knyshova mountain (Melnyk \& Parubok, 2004);

25) Halych district, outskirts of Bovshiv village, Kasova mountain (Kahalo, 1988, LW; Kuziarin, 1991, LWS; Drapailo, 2002, KW; Dmytrash \& Shumska, 2011; Skoroplias, 2012);

26) Halych district, outskirts of Bovshiv village, Dachne Tract (Dmytrash \& Shumska, 2011);

27) Halych district, near Mezhyhirtsi village, Kamin Tract (Dmytrash \& Shumska, 2011);

28) Halych district, outskirts of Hohoniv village, Brucheva Tract (Dmytrash \& Shumska, 2011);

29) Halych district, outskirts of Meduha village, the Simlyn Tract (Dmytrash \& Shumska, 2011);

30) Halych district, Korostovychi village, Hora Hareva Tract (Dmytrash \& Shumska, 2011);

31) Halych district, Byshiv village, Horozhanka Tract (Dmytrash \& Shumska, 2011; Skoroplias, 2014);

32) Rohatyn district, outskirts of Luchyntsi village Velyki Holdy Tract (Dmytrash \& Shumska, 2011);

Ternopil region

33) Berezhany district, the outskirts of Demnia village, Mohyla mountain (Melnyk \& Parubok, 2004; Skoroplias, KWHA, 2011);

34) Berezhany district, the outskirts of Hutysko and Demnia villages, the Holytsia mountain (Melnyk \& Parubok, 2004);

35) Pidvolochysk district, Horodnytsia village, meadow steppe on the second Horodnytsky Hill (Kahalo, 1995, LWKS; Oliar, 2010; Skoroplias, KWHA, 2013);

36) Pidhaitsi district, outskirts of Nosivka village, the Pid Konem Tract (Skoroplias, KWHA, 2013).

Khmelnytsky region

37) Khmelnytsky (Shmalhausen, 1886, KW);

38) Iziaslav district, the Adamove Zaimysko Tract (Zvedeniuk, Melnyk \& Batochenko, 2005, KWHA; Melnyk \& Skoroplias, 2011, KWHA);

39) Letychiv district, Lysohorka village (Montrezor, 1998, KW);

40) Letychiv district, Medzhybizh village (Montrezor, 1998, KW);

41) Krasyliv district, Velyki Zozulentsi village (Klokov, 1962).

Vinnytsia region

42) Kalynivka district, the outskirts of Velyki Kutyshcha village (Klokov, 1962);

43) Vinnytsia (Klokov, 1962);

44) Lypovets district (Klokov, 1962);

45) Nemyriv district, Luka village (Klokov, 1962).

Thus, throughout the period of floristic surveys in the lowland part of Ukraine, a total of 45 localities with C. cirsioides (Fig. 1) were recorded, 15 of which by now have gone.

Habitats and modern state of the populations. We provide phytocoenotic descriptions and modern stste of populations of $C$. cirsioides in the locations we surveyed.

Volhynian Polissia

Habitat of C. cirsioides was found in 39th quarter of the Liubomyrsk Forestry near the Railway Station Liubomyrsk, which is allocated with forest cultures of Quercus robur L. The trees are around 50 years old, the average trunk diameter measuring $25 \mathrm{~cm}$, and the average tree height equaling $18 \mathrm{~m}$. The tree layer includes single trees of Carpinus betulus L., Populus tremula L., Pyrus communis L. The herb layer is thinned-out, and its projective cover equaled $50 \%$. It was formed by Anthericum ramosum L., Betonica officinalis L., Campanula persicifolia L., Convallaria majalis L., Fragaria vesca L., Melampyrum nemorosum L., Maianthemum bifolium (L.) F. W. Schmidt, Digitalis grandiflora Mill. There we found only two single specimens of $C$. cirsioides.

The Podolian Upland

The Mohyla Mountain looks like a rounded hill elevated up to $100 \mathrm{~m}$ above the surroundings with slanted slopes $\left(10-20^{\circ}\right)$ and is located near the Holytsia Mountain in the outskirts of Hutysko village of Berezhany district of Ternopil region. The area of the mountain accounts for 32 ha. Plant cover of this mountain is represented by meadow steppe. The floristic composition of this mountain is similar to the meadow steppe flora of the Holytsia Mountain, though slightly poorer. The projected area of 
plants is $100 \%$, projected area of $C$. cirsioides is about $5 \%$. The species which formed formations are Cariceta humilis and Bromopsideta inermis, which are represented there by associations Carex humilis + Bromopsis inermis, Bromopsis inermis + Carex humilis. The dominants are Carex humilis Leys. (30\%), Bromopsis inermis (Leys.) Holub (20-30\%), codominants - Rhinanthus minor L.(10\%), Thalictrum minus L. (10\%). The herbaceous-shrub layer comprises also Adonis vernalis L., Anthericum ramosum L., Anthyllis macrocephala Wender, Asperula cynanchica L., Astragalus austriacus Jacq., Brachypodium pinnatum (L.) P. Beauv., Betonica officinalis L., Briza media L., Centaurea jacea L., C. scabiosa L., Coronilla varia L., Dactylorhiza sambucina (L.) Soo, Euphorbia stricta L., Galium verum L., Geranium sanguineum L., Gypsophylla fastigiata L., Gymnadenia conopsea (L.) R. Br., Filipendula vulgaris Moench, Inula ensifolia L., Knautia arvensis (L.) Coult., Lembotropis nigricans (L.) Griseb., Leucanthemum vulgare Lam., L. ambiguous Besser ex Spreng., Medicago procumbens Besser, Orobanche lutea Baumg., Pedicularis vulgaris L., Primula veris L., Plantago media L., Salvia pratensis L., S. verticillata L., Sanguisorba officinalis L., Stachys recta L., Teucrium montanum L., Trifolium montanum L., T. rubens L., Valeriana stolonifera Czern. The population of $C$. cirsioides is small, containing around 150 specimens (Table). Plants are arranged as groups, 10-12 specimens in each.

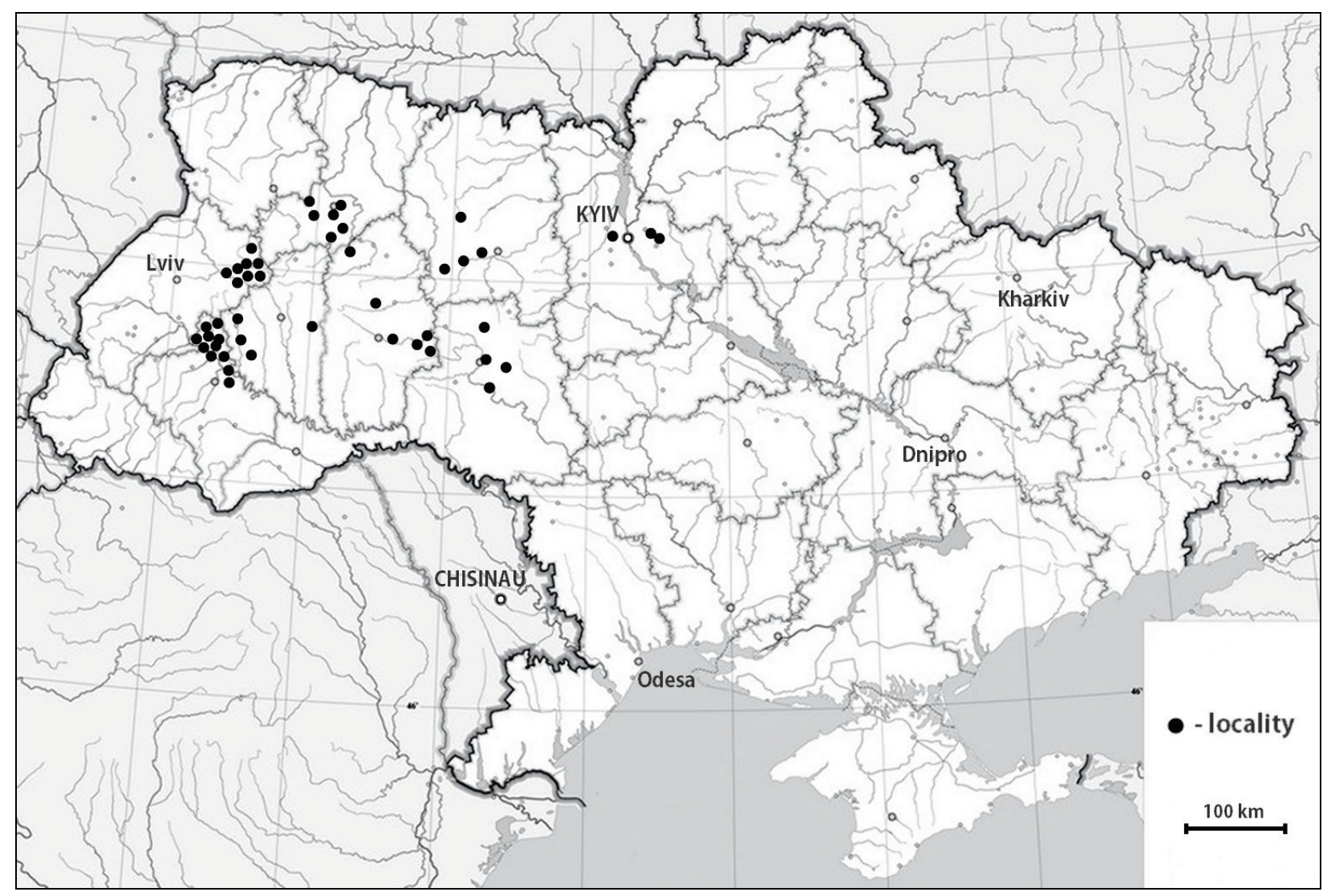

Fig. 1. Geografical distribution of Carlina cirsioides (= Carlina acaulis caulescens) in lowlands of Ukraine

The Zarvanytsia Mountain is located in the outskirts of Zarvanytsia village of Zolochivsky district of Lviv region, which belongs to the geomorphological district Voroniaky (North-West Podillia). Soils are sodcarbonate. The vegetation is represented by formations of Dactyleta glomeratae, Brachypodieta pinnati, which compose associations Dactylis glomerata + Galium verum, Brachypodium pinnatum + Poa pratensis. The dominants are Dactylis glomerata L. (30\%), Galium verum L. (20\%), Brachypodium pinnatum (L.) P. Beauv. (30\%), Poa pratensis L. (20\%), Molinia caerulea (L.) Moench (30\%), Anthericum ramosum L. (20\%), co-dominants are C. cirsioides (10\%), Veratrum nigrum L. (15\%). The herbaceous layer comprises also Achillea millefolium L., Artemisia vulgaris L., Asparagus officinalis L., Anemona narcissiflora L., Campanula glomerata L., C. persicifolia L., Calamagrostis epigeios (L.) Roth, Carlina vulgaris L., Centaurea jacea L., Chamaecytisus ruthenicus D., Cichoricum intybus L., Digitalis grandiflora Mill., Echium vulgare L., Elytrigia repens (L.) Nevski, Eryngium campestre L., Eupatorium cannabinum L., Euphrasia officinalis L., Fragaria viridis L., Gentianella amarella (L.) Boern., Geranium sanguineum L., Hieracium pilosella L., Lilium martagon L., Mercurialis ovata Sternb., Medicago falcata L., Origanum vulgare L., Orobanche ramosa L., Plantago lanceolata L., P. media L., Primula veris L., Prunella grandiflora (L.) Scholl., Ranunculus zapalowiczii Pacz, Salvia pratensis L., Senecio umbrosus Waldst. et Kit, Sesleria caerulea (L.) Ard., Succicella inflexa (Kluk.) G.Beck, Tanacetum vulgare L., Taraxacum officinalle Wigg., Thalictrum minus L., Trifolium alpestre L., Tussilago farfara L., Valeriana officinalis L., Vera- trum nigrum $\mathrm{L}$. The population of $C$. cirsioides on the Zarvanytsia Mountain is the most numerous, comprising over one thousand plants. Among them, $81.2 \%$ of the specimens are generative and $12.1 \%$ are vegetative, $4.6 \%$ immature and $2.1 \%$ juvenile. The density of the population measures $1-12$ specimens $/ \mathrm{m}^{2}$, and up to 14 specimens $/ \mathrm{m}^{2}$ in some places (Table).

The Horodnytski Tovtry is located in the outskirts of Horoden village of Pidvolochynsky district of Ternopil region within the Medobory Nature Reserve. The area accounts for 1 ha. The soils are chernozems. The vegetation is represented by formation of Elytrigieta repentis and Anthericeta ramosi, which form associations Elytrigia repens + Melamphyrum arvense, Anthericum ramosum + Brachypodium pinnatum. Projected area of the grass stand is $90 \%$. The dominants are Elytrigia repens (L.) Nevski (25\%), Anthericum ramosum L. (30\%), co-dominants - Melamphyrum arvense L. (20\%), Brachypodium pinnatum (L.) P. Beauv (20\%). Projected area of Carlina cirsioides equals 5\%. The herbaceous cover also includes Adonis vernalis L., Achillea millefolium L., Agrimonia eupatoria L., Aster amellus L., Asperula cynanchica L., Betonica officinalis L., Briza media L., Campanula bononiensis L., C. rapunculoides L., Carex montana L., Centaurea scabiosa L., Chamaecytisus austriacus (L.) Link, Helictotrichon pubescens (Huds.) Dumort., Clinopodium vulgare L., Dactylis glomerata L., Echium maculatum L., Euphorbia angulata Jang., Galium verum L., Filipendula vulgaris Moench, Fragaria viridis Duchesne, Hypericum perforatum L., Inula aspera Poir., Knautia arvensis (L.) Coult., Koeleria cristata L., Leucanthemum vulgare Lam., Linum catharticum L., Linaria vulgaris L., Medicago falcata L., Pulsatilla gran- 
dis Wender, Peucedanum oreoselinum L. (Moench), Pedicularis kaufmanni Pinzg., Prunella grandiflora (L.) Scholl., Primula veris L., Potentilla alba L., Salvia verticillata L., S. dumetorum Andrz., Thalictrum simplex L., T. minus L., Thesium linophyllon L., Teucrium chamaedrys L., Trifolium montanum L., T. medium L., Vincetoxicum hirundinaria Medik., Viola hirta L., Viscaria vulgaris L. In the territory of the Horodnytski Tovtry, the population is small, comprising around 580 specimens. The density of the population is on average $1-6$ specimens $/ \mathrm{m}^{2}$, the largest one containing 10-20 specimens $/ \mathrm{m}^{2}$ (Table).

Pid Konem Tract is located in the outskirts of Nosivka village of Pidhaitsi district of Ternopil region. The site is located within a slope of northern exposure, bordering with farmlands in the south and abandoned degraded lands in the north, and the forests of the State Distrct Forestry Berezhanyraiahrolis in the west. The area of the site accounts for 1 ha. The soils are chornozems. The vegetation is represented by the formation of Brachypodieta pinnati, which forms association between Brachypodium pinnatum + Elytrigia intermedia. Projected area of the grass stand is $95 \%$. The dominants are Brachypodium pinnatum (L.) P. Beauv (30\%), Elytrigia intermedia (Host) Nevski (25\%). The projected area of $C$. cirsioides equals $<1 \%$. The herbaceous layer includes also Achillea millefolium L., Achyrophorus maculatus (L.) Scop., Agrimonia eupatoria L., Anthericum ramosum L., Anthyllis macrocephala Wender., Anthyllis schiwereckii (DC) Blocki, Aruncus vulgaris Rafin, Asperula cynanchica L., Astrantia major L., Betonica officinalis L., Briza media L., Campanula glomerata L., C. persicifolia L., Carex montana L., Centaurea jacea L., C. phrygia L., C. scabiosa L., C. stricta Waldst. et Kit, Cirsium erisithales (Jacq.) Scop, Cruciata glabra (L.) Ehrend, Coronilla varia L., Helictotrichon pubescens (Huds.) Pilg., Clematis recta L., Dactylis glomerata L., Digitalis grandiflora Mill., Dianthus armeria L., D. carthusianorum (Kit.) Borbas, Euphorbia angulata Jacq., Eurhorbia ciparissias L., Galium album L., G. exoletum Klok, G. odoratum (L.) Scop., Genista tinctoria L., Geranium sanguineum L., Gentiana cruciata L., Festuca valesiaca Gaudin, Filipendula vulgaris Moench, Fragaria viridis Duchesne, Helianthemum nummularium (L.) Mill., Hypericum elegans Steph. ex Willd, Inula aspera Poir., Knautia arvensis (L.) Coult., Koeleria cristata (L.) Pers., Lathyrus niger (L.) Bernh., L. pratensis L., Lembotropis nigricans (L.) Griseb., Leucanthemum vulgare Lam., Lotus ucrainikus Klok., Linum catharticum L., L. flavum L., Medicago romanica Prod., Melilotus officinalis L., Mercurialis ovata Sternb. Hoppe, Molinia caerulea (L.) Moench, Onobrychis arenaria (Kit.) DC., Origanum vulgare L., Pulmonaria mollis Wulf. ex Hornem., Peucedanum cervaria (L.) Lapeyr., Prunella grandiflora (L.) Scholl, Primula veris L., Potentilla alba L., P. erecta (L.) Raeusch., Pyrethrum corymdosum (L.) Scop., Plantago media L., P. lanceolata L., Rosa sherardii Davies, Rosa tomentosa Smith, Rhinanthus minor L., Salvia verticillata L., S. dumetorum Andrs., Sanguisorba officinalis L., Serratula tinctoria L., Symphytum besseri Zaverucha., Scorzonera purpurea L., Senecio vulgaris L., Stachys recta L., Thymus marschallianus Willd., Thalictrum minus L., Thesium linophyllon L., Teucrium chamaedrys L., Trifolium pannonicum Jacg., T. montanum L., T. medium L., Valeriana stolonifera Czern., Veratrum lobelianum Berch. In the Pid Konem Tract, the population of $C$. cirsioides is small, comprising 35 specimens. The density of the population is on average $1-6$ specimens $/ \mathrm{m}^{2}$, the largest being 9-10 specimens $/ \mathrm{m}^{2}$ (Table).

Makitra Mountain is located near Buchino village of Brody district of Lviv region. The soils are sod-podzolized. Meadow-steppe vegetation is represented by formation of Cariceta humilis with associations Carex humilis + Bromopsis inermis + Thalictrum foetidum. The projected area of the grass stand equals $100 \%, C$. cirsioides $<1 \%$. The herbaceous cover also contains Anthericum ramosum L., Allium montanum F. W. Schmidt., Aster amellus L., Carex hirta L., Centaurea sanguineum L., Euphorbia cyparissias L., Gypsophylla thyraica A. Krasnova, Inula ensifolia L., Lembotropis nigricans (L.) Griseb., Prunella grandiflora (L.) Scholl., Polygonatum odoratum (Mill) Druce, Salvia verticillata L., Thalictrum foetidum L., Vincetoxicum officinale Moench. Only 3 specimens of $C$. cirsioides were found on Makitra Mountain (Table).

Holohirka Tract is located north of Stinka village of Zolochiv district of Lviv region. The area of the site accounts for $150 \mathrm{~m}^{2}$. The soils are sodpodzolized. The vegetation is represented by formation of Elytrigieta intermedia - association between Elytrigia intermedia + Inula ensifolia.
The projected area of the grass stand is $90 \%$. The dominants are Elytrigia intermedia (Host) Nevski (40\%), co-dominants - Inula ensifolia L. (30\%). The projected area of $C$. cirsioides equals $5-10 \%$. The herbaceous cover also includes Aegopodium podagraria L., Adonis vernalis L., Anemone sylvestris L., Anthericum ramosum L., Agrimonia eupatoria L., Carlina vulgaris L., Campanula persicifolia L., Carex humilis Leys, Centaurea scabiosa L., Cephalantera damasonium (Mill.) Druce, Dactylis glomerata L., Iris hungarica Waldst. et Kit., Melittis melissophyllum L., Origanum vulgare L., Salvia verticillata L., Thesium linophyllon L., Trifolium rubens L. In the Holohirka Tract the population of $C$. cirsioides is small, comprising about 627 specimens. The average density of the population is $2-9$ specimens $/ \mathrm{m}^{2}$, and the highest is $10-19$ specimens $/ \mathrm{m}^{2}$ (Table).

Chortova Mountain is a Botanical Monument of National Significance, it is located between Pukiv and Babyntsi villages of Rohatyn district of Ivano-Frakivsk regiont. The area of the protected territory is 13 ha. The mountain is a butte with steep $\left(20-30^{\circ}\right)$ slopes, elevated $100-150 \mathrm{~m}$ above the surrounding surface. The soils are podzolized chornozems. The meadow-steppe vegetation is represented by formations of Brachypodieta pinnati and Cariceta humilis, which are represented by associations Brachypodium pinnatum + Carex humilis, Carex humilis + Anthericum ramosum. The projected area of the grass stand is $100 \%$, that one of C. cirsioides measures from $15 \%$. The herbaceous cover is also composed of Achillea millefolium L., Aconitum moldavicum Hacq., Adonis vernalis L., Anemone sylvestris L., Aster amellus L., Betonica officinalis L., Bromopsis inermis (Leuss.) Holub, Centaurea sanguineum L., Dactylis glomerata L., Elytrigia intermedia (Host) Nevski, Euphorbia cyparissias L., Filipendula vulgaris Moench, Galium verum L., Geranium sanguineum L., Hypericum perforatum L., Inula ensifolia L., Iris hungarica Waldst. et Kit., Lembotropis nigricans (L.) Griseb, Medicago lupulina L., Pencedanum cervaria (L.) Lapeyr, Plantago media L., Prunella grandiflora (L.) Scholl., Pulsatilla latifolia Rupr., Polygonatum odoratum (Mill.) Druce, Poa pratensis L., Ranunculus acrius L., Salvia verticillata L, Sanguisorba officinalis L., Scabiosa ochroleuca L., Solidago virguaurea L., Stachys recta L., Trifolium rubens L., Thalictrum minus L., Veratrum nigrum L. The population of the species on the Chortova Mountain is one of the largest. It includes around 1,000 specimens, with the density of 10 20 specimens $/ \mathrm{m}^{2}$.

Kasova Mountain (Fig. 2) is located west of Bovshiv village of Halych district of Ivano-Frankivsk region. It is a steppe reserve within the Halych National Nature Park. The area of the reserve is 160 ha. The mountain stretches $4 \mathrm{~km}$ along the left slope of the Hnyla Lypa River and the Burshtyn Water Reserve. The mountain is $340 \mathrm{~m}$ above sea level and $100 \mathrm{~m}$ above the valley of the Hnyla Lypa River.

The meadow-steppe vegetation is represented by formations of $\mathrm{An}$ thericeta ramosum, Brachypodieta pinnati, composed of associations between Anthericum ramosum + Carex humilis, Brachypodium pinnatum + Carex humilis, Brachypodium pinnatum + Anthericum ramosum (Fig. 2). The projected area of the vegetative layer is $100 \%$, that one of $C$. cirsioides is less than 1\%. The vegetative cover includes Achillea millefolium L., Adonis vernalis L., Agrimonia eupatoria L., Anemone sylvestris L., Anthyllis schiwereckii (DC) Bloski, Astragalus onobrychis L., Asperula cynanchica L., Betonica officinalis L., Briza media L., Campanula glomerata L., Centaurea scabiosa L., Cerastium arvense L., Chamaecytisus blockianus (Pawt.) Klask., Elytrigia repens (L.) Nevski, Festuca pratensis Huds., Filipendula vulgaris Moench, Galium boreale L., Geranium sanguineum L., Gypsophylla fastigiata L., Inula hirta L., Knautia arvensis (L.) Coult., Lembotropis nigricans (L.) Griseb, Lotus corniculantus L., Linum flavum L., Medicago falcata L., Melampyrum nemorosum L., Melica mutans L., Ononis arvensis L., Origanum vulgare L., Plantago media L., Pteridium aquilinum (L.) Kuhn, Prunella grandiflora (L.) Scholl., Salvia verticillata L., Scabiosa ochrolenca L., Solidago virguaurea L., Succisa pratensis L., Teucrium chamaedrys L., Trifolium rubens L., Thalictrum foetidum L., Vicia cracca L., Veronica chamaedrys L. The population of $C$. cirsioides on the Kasova Mountain is large, comprising over 967 specimens, which occupy the area of about 1.5 ha in the central part of the mountain.

The Horozhanka Tract is located between Byshiv village of Halych district of Ivano-Frankivsk Oblast and Horozhanka village of Pidhaitsi district of Ternopil region. Near the foothills of the mountain, the vegeta- 
tion is represented by the formations of Festuceta rubrae with associations Festuca rubra + Elytrigia repens + Filipendula vulgaris, Centaurea sanguineum + Festuca rubra. The projected area of the herbaceous layer equals $90 \%$, that of $C$. cirsioides (5-15\%), Anthericum ramosum L. (50\%), Bromopsis inermis (Leuss.) Holub (30\%), Centaurea sanguineum L. (10-40\%), Elytrigia repens (L.) Nevski (20\%), Festuca rubra L. (3050\%). Herbaceous layer also includes Achillea millefolium L., Adonis vernalis L., Allium podolicum (Asch. \& Graebn.) Blocki ex Racib, Betonica officinalis L., Carex humilis Leys, Chamaecytisus blockianus (Pawt.) Klask., Dactylis glomerata L., Euphorbia cyparissias L., Fragaria vesca
L., Filipendula vulgaris Moench, Galium verum L., Hypericum perforatum L., Lembotropis nigricans (L.) Griseb, Lilium martagon L., Medicago falcata L., M. lupulina L., Potentilla alba L., Ranunculus acris L., Salvia verticillata L., Sanguisorba officinalis L., Scabiosa ochroleuca L., Solidago virguaurea L., Teucrium chamaedrys L., Trifolium pratense L., Thalictrum aquilegifolium L., Viola odorata L., Veronica spicata L. The population of $C$. cirsioides in the Horozhanka Tract is small, occypying the area of around 0.5 ha in the central part of the mountain, at 316 specimens. Plants grow singly and in small groups of 5-20 speci$\mathrm{mens} / \mathrm{m}^{2}$

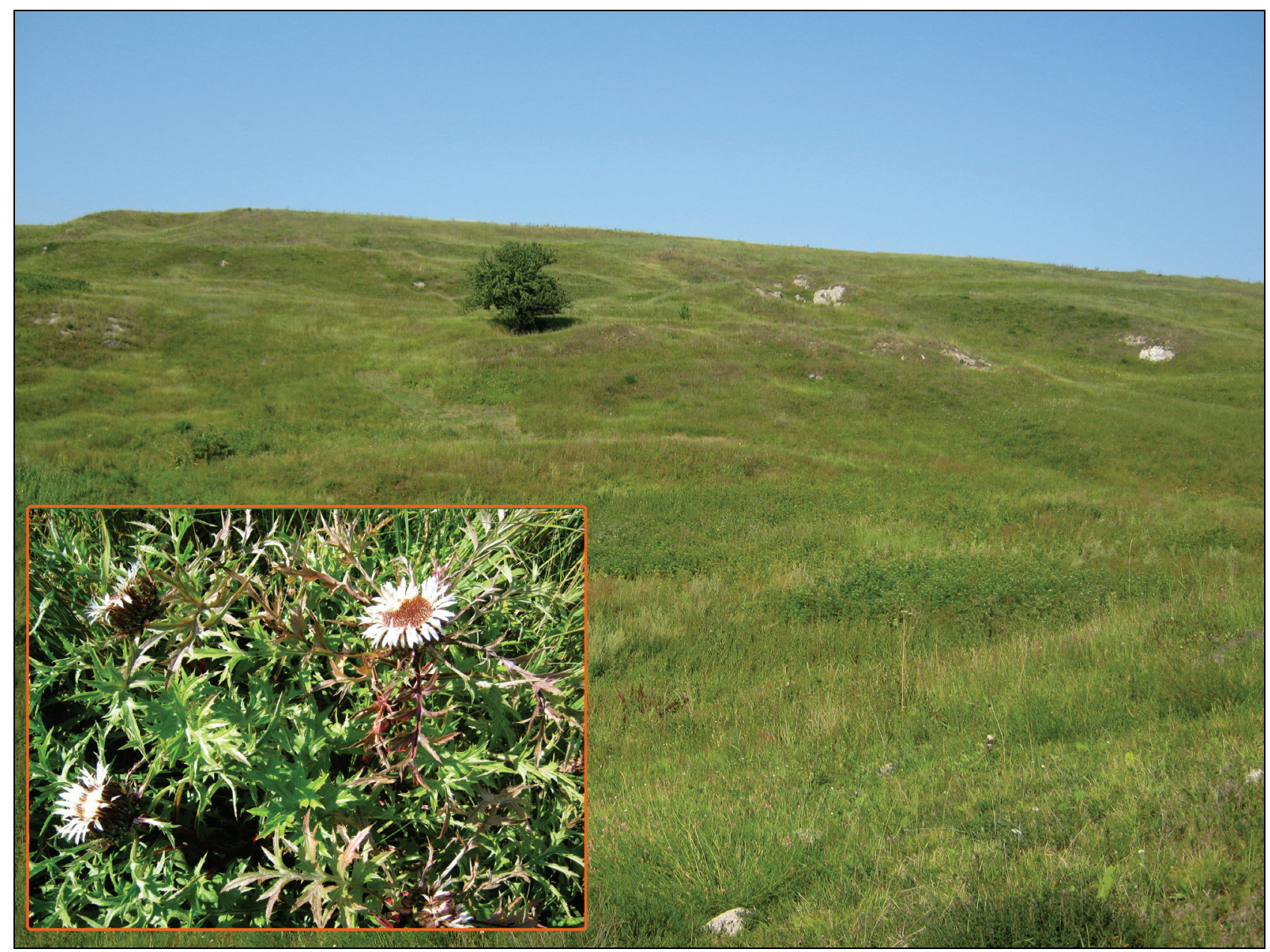

Fig. 2. Habitat of Carlina cisioides (= C. acaulis caulescens) in Kasova Hora (Podolian Upland, Ivano-Frankivsk region, Halycky national natural park)

The Simlyn Tract is located near Meduha village of Halych district of Ivano-Frankivsk region. The local population of $C$. cirsioides is confined to the meadows on flat interfluves at the distance of $60 \mathrm{~m}$ from the Simlyn Forest which is included in the Halych National Nature Park. The site is completely surrounded by arable agricultural fields. The area of the site accounts for 13.4 ha. The vegetation is represented by formation of $\mathrm{Bra}$ chypodieta pinnati with association Brachypodium pinnatum + Molinia caerulea + Elytrigia repens. Projected area of the grass stand is $100 \%$. The dominants are Brachypodium pinnatum (L.) P. Beauv (50\%), codominants - Molinia caerulea (L.) Moench (40\%), Elytrigia repens (L.) Nevski (20\%). Projected area of $C$. cirsioides equals $<1 \%$. The herbaceous layer comprises Adenophora lilifolia (L.) A. DC, Anthericum ramosum L., Betonica officinalis L., Campanula glomerata L., Centaurea sanguineum L., Chamaecytisus blockianus (Pawt.) Klask., Chenopodium album L., Filipendula vulgaris Moench, Galium verum L., Holcus lanatus L., Lembotropis nigricans (L.) Griseb, Lysimachia nummularia Aurea, Lilium martagon L., Origanum vulgare L., Polygonatum odoratum (Mill.) Druce, Rubus caesius L., Sanguisorba officinalis L., Solidago virguaurea L., Tanacetum vulgare L., Thalictrum aquilegifolium L., Vicia cracca L., Veratrum nigrum L. The population of $C$. cirsioides in the Simlyn Tract is small ( 89 specimens), the plants grow singly and in small groups of 5-14 specimens $/ \mathrm{m}^{2}$ (Table).
The local population of $C$. cirsioides in the Brucheva Tract on the outskirts of Hohoniv village of Halych district is confined to the middle and the lower parts of the north-west slope of the hill. The soils are podzolized chornozems of up to $50 \mathrm{~cm}$ thickness, formed on limestones. Vegetation is represented by the formation of Brachypodieta pinnati which forms the association Brachypodium pinnatum + Sesleria caerulea. Projected area of the grass stand is $100 \%$. The dominants are Brachypodium pinnatum (L.) P. Beauv (40\%), co-dominants - Sesleria caerulea (L.) Ard. (30\%). Projected area of $C$. cirsioides is $<1 \%$. The herbaceous layer is composed of Achillea millefolium L., Anthericum ramosum L., Aster amellus L., Asperula odorata L., Betonica officinalis L., Bromopsis inermis (Leys.) Holub, Briza media L., Campanula glomerata L., Carex montana L., Carlina vulgaris L., Centaurea scabiosa L., C. stricta Waldst. \& Kit., Chamaecytisus blockianus (Pawt.) Klask., Coronilla varia L., Clematis recta L., Dactylis glomerata L., Euphorbia helioscopia L., Filipendula vulgaris Moench, Hieracium umbellatum L., Lilium martagon L., Medicago falcata L., Pyrethrum corymbosum (L.) Scop., Prunella grandiflora (L.) Scholl., Salvia verticillata L., Sanguisorba officinalis L., Sesleria heufleriana Schur, Solidago virguaurea L., Tanacetum vulgare L., Teucrium chamaedrys L., Thalictrum minus L. In the Brucheva Tract, the population of $C$. cirsioides is small, comprising 33 individuals; the plants grow singly and in small groups of 6-14 individuals $/ \mathrm{m}^{2}$ (Table). 
The Hora Hareva Tract of 9.6 ha area is located near Korostovychi village of Halych disrict of Ivano-Frankivsk region. Near the foothill, the herbaceous layer is represented by the formation of Brachypodieta pinnati with association between Brachypodium pinnatum + Festuca valesiaca. The projected area of herbaceous layer is $90 \%$, and that of $C$. cirsioides $<$ $1 \%$. The dominants are Brachypodium pinnatum (L.) P. Beauv (50\%) and Festuca valesiaca Gaudin (30\%). The vegetation also includes Adonis vernalis L., Anthericum ramosum L., Asperula cynanchica L., Briza media L., Centaurea scabiosa L., Filipendula vulgaris Moench, Inula ensifolia L., Lembotropis nigricans (L.) Griseb, Peucedanum cervaria (L.) Lapeyr, Pulsatilla grandis Wender, Salvia verticillata L., Scabiosa ochrolenca L., Succisa pratensis L., Stachys recta L., Teucrium chamaedrys L., Thalictrum minus L., Vincetoxicum officinale Moench. The population of $C$. cirsioides in the Hora Hareva Tract is small, occypying the area of $100 \mathrm{~m}^{2}$ in the central part of the mountain. It consists of $23.0 \%$ immature, $30.8 \%$ vegetative, and $46.2 \%$ generative individuals. The plants grow singly and in small groups of 6-13 individuals $/ \mathrm{m}^{2}$.

The Kamin Tract is located near Mezhyhirtsi village of Halych district of Ivano-Frankivsk region. The northern slope ( $25^{\circ}$ steep) is covered by meadow-steppe grass-forbes vegetation. The soils are podzolized chornozems. The vegetation is presented by formation of Brachypodieta pinnati with association Brachypodium pinnatum + Inula ensifolia. Projected area of the grass stand is $100 \%$. The dominants are Brachypodium pinnatum (L.) P. Beauv (60\%) and Inula ensifolia L. (30\%). Projected area of C. cirsioides equals 5\%. The herbaceous layer comprises Agrimonia eupatoria L., Anemone sylvestris L., Anthericum ramosum L., Aster amellus L., Asperula cynanchica L., Betonica officinalis L., Briza media L., Campanula glomerata L., Carex humilis Leys, Centaurea scabiosa L., C. rhenana Boreau, Euphorbia cyparissias L., Eryngium campestre L., Filipendula vulgaris Moench, Galium verum L., Geranium sanguineum L., Iris hungarica Waldst. et Kit., Lotus corniculanus L., Medicago falcata L., Melampyrum nemorosum L., Origanum vulgare L., Pencedanum oreoselinum L., Plantago media L., Prunella grandiflora (L.) Scholl.,
Pulsatilla grandis Wender, Salvia verticillata L., Scabiosa ochroleuca L., Teucrium chamaedrys L. Because forbs, particularly grasses, have significantly overgrown the slopes of the mountain, rare species, particularly C. cirsioides, may soon vanish. The population of $C$. cirsioides in the Kamin Tract is small, with around 138 indiviuals counted. The plants grow singly and in small groups of 5-12 individuals $/ \mathrm{m}^{2}$.

The Adamove Zaimysko Tract is located in the lands of Radoshiv village of the Council of Iziaslav district of Khemelnytska region, near Plishchyn village of Shepetivsky district of Khmelnytsk region. The area accounts for 7.5 ha. The soils are sod-podzolized, loamy-sandy.

The growing location is confined to the ecotone between oak-hornbeam forest and meadows in the valley of the ravine. At the edge of the forest, Betula verrucosa Ehrh grows, young undergrowth of which is massively invading the neighbouring meadows. There are separate trees of Quercus robur L., Cerasus avium (L.) Moench., Salix caprea L., and dense thickets of Crataegus monogyna Jacq., Prunus spinosa L., Rosa canina L., Rubus caesius L. and Chamaecytisus ruthenicus D.

In the diverse herbaceous layer, the dominant species are Festuca pratensis Huds., along with which there grow Achillea millefolium L., Agrimonia eupatoria L., Betonica officinalis L., Carex hirta L., Campanula persicifolia L., Centaurea jacea L., Cimicifuga europaea Schipcz., Convallaria majalis L., Crepis biennis L., Dactylis glomerata L., Dentaria bulbifera L., Fragaria verna (L.) Crantz, Galium odoratum (L.) Scop., Geum rivale L., Geranium palustre L., Helianthemum nummularium (L.) Mill., Lathyrus vernus (L.) Bernh., Lysimachia nummularia Aurea, Pimpinella saxifraga L., Polygonatum multiflorum (L.) All., Potentilla alba L., P. erecta (L.) Raeusch., Primula veris L., Serratula tinctoria L., Succisella inflexa (Kluk) G. Beck, Tanacetum vulgare L., Thalictrum aquilegifolium L., Thymus serpyllum L., Trifolium rubens L., Veratrum nigrum L., Carlina cirsioides Klokov. The population of $C$. cirsioides in the Adamove Zaimysko Tract is small, only 62 individuals of this species were found. Spectra of ontogenetic stages of surveyed populations of $C$. cirsioides are presented in the Table (Table).

Table

Spectra of ontogenetic stages of populations of Carlina cirsioides in Ukraine

\begin{tabular}{|c|c|c|c|c|c|c|c|c|c|c|c|}
\hline \multirow{3}{*}{ Location } & \multirow{3}{*}{ Formations } & \multirow{3}{*}{$\begin{array}{l}\text { Area, } \\
\mathrm{m}^{2}\end{array}$} & \multirow{3}{*}{$\begin{array}{l}\text { Total } \\
\text { number }\end{array}$} & \multicolumn{8}{|c|}{ Spectra of ontogenetic stages } \\
\hline & & & & $\mathrm{j}$ & & $\mathrm{im}$ & & $\mathrm{v}$ & & & $\mathrm{g}$ \\
\hline & & & & $\begin{array}{c}\text { indivi- } \\
\text { duals }\end{array}$ & $\%$ & $\begin{array}{l}\text { indivi- } \\
\text { duals }\end{array}$ & $\%$ & $\begin{array}{c}\text { indivi- } \\
\text { duals }\end{array}$ & $\%$ & $\begin{array}{c}\text { indivi- } \\
\text { duals }\end{array}$ & $\%$ \\
\hline $\begin{array}{l}\text { Mohyla Mountain (outskirts of Hutysko village, Berezh } \\
\text { district, Ternopil region) }\end{array}$ & $\begin{array}{l}\text { Cariceta humilis, } \\
\text { Bromopsieta inermis }\end{array}$ & 20000 & 150 & 13 & 8.6 & 25 & 16.7 & 79 & 52.7 & 33 & 22.0 \\
\hline $\begin{array}{l}\text { Sypuha Mountain (outskirts of Chervone village, Zolochiv } \\
\text { district, Lviv region) }\end{array}$ & $\begin{array}{l}\text { Festuceta valesiacae, } \\
\text { Helictotrichoneta deser- } \\
\text { torum, Inuleta ensifoliae }\end{array}$ & 100 & 25 & 3 & 12.0 & 7 & 28.0 & 8 & 32 & 7 & 28.0 \\
\hline $\begin{array}{l}\text { Kasova Mountain Tract (outskirts of Bovshiv village, } \\
\text { Halych district, Ivano-Frankivsk region) }\end{array}$ & $\begin{array}{l}\text { Anthericeta ramosum, } \\
\text { Brachypodieta pinnati }\end{array}$ & 15000 & 967 & 94 & 9.7 & 79 & 8.2 & 278 & 28.7 & 516 & 53.4 \\
\hline $\begin{array}{l}\text { Hora Hareva Tract (near Korostovychi village, Halych } \\
\text { district, Ivano-Frankivsk region) }\end{array}$ & Brachypodieta pinnati & 100 & 65 & 0 & 0 & 15 & 23.0 & 20 & 30.8 & 30 & 46.2 \\
\hline $\begin{array}{l}\text { Kamin Tract (near Mezhyhirtsi village, Halych district, } \\
\text { Ivano-Frankivsk region) }\end{array}$ & Brachypodieta pinnati & 345 & 138 & 0 & 0 & 13 & 9.4 & 29 & 21.0 & 96 & 69.6 \\
\hline $\begin{array}{l}\text { Horozhanka Tract (between Byshiv village of Halych } \\
\text { district of Ivano-Frankivsk region and Horozhanka village } \\
\text { of Pidhaitsi district, Temopil region) }\end{array}$ & Festr & 200 & 316 & 2 & 0.6 & 4 & 1.3 & 26 & 8.2 & 284 & 89.9 \\
\hline $\begin{array}{l}\text { Simlyn Tract (outskirts of Meduha village, Halych district, } \\
\text { Ivano-Frankivsk region) }\end{array}$ & Brachypodieta pinnati & 13400 & 89 & 0 & 0 & 4 & 4.5 & 14 & 15.7 & 71 & 79.8 \\
\hline $\begin{array}{l}\text { Brucheva Tract (outskirts of Hohoniv village, Halych } \\
\text { district, Ivano-Frankivsk region) }\end{array}$ & Brachypodieta pinnati & 300 & 33 & 0 & 0 & 0 & 0 & 5 & 15.2 & 28 & 84.8 \\
\hline $\begin{array}{l}\text { Makitra Mountain (outskirts of Buchyno village, Brody } \\
\text { district, Lviv region) }\end{array}$ & Cariceta humilis & 8 & 3 & 0 & 0 & 0 & 0 & 1 & 33.3 & 2 & 7 \\
\hline $\begin{array}{l}\text { Holohirka Tract (Stinka village, Zolochiv district, Lviv } \\
\text { region) }\end{array}$ & Elytrigieta intermedia & 150 & 627 & 0 & 0 & 122 & 19.5 & 135 & 21.5 & 370 & 59.0 \\
\hline $\begin{array}{l}\text { Adamove Zaimysko Tract (outskirts of Plishchyn village, } \\
\text { Shepetivsky district, Khmelnytsk region) }\end{array}$ & Dactuletum glomeratum & 50 & 62 & 0 & 0 & 2 & 3.2 & 10 & 16.1 & 50 & 80.7 \\
\hline $\begin{array}{l}\text { Chortova mountain (between villages Pukiv and Babyntsi, } \\
\text { Rohatyn district, Ivano-Frankivsk region) }\end{array}$ & $\begin{array}{l}\text { Brachypodieta pinnati, } \\
\text { Cariceta humilis }\end{array}$ & 50000 & 1000 & 40 & 4.0 & 248 & 24.8 & 562 & 56.2 & 150 & 15.0 \\
\hline $\begin{array}{l}\text { Horodnytski Tovtry Park (outskirts of Horoden village, } \\
\text { Pidvolochynsky district, Ternopil region) }\end{array}$ & Elyt & 10000 & 580 & 21 & 3.6 & 124 & 21.4 & 81 & 14.0 & 354 & 0 \\
\hline $\begin{array}{l}\text { Pid Konem Tract (Nosivka village, Pidhaitsi district, Ter- } \\
\text { nopil region) }\end{array}$ & Brachypodieta pinnati & 10000 & 35 & 2 & 5.7 & 10 & 28.6 & 11 & 31.4 & 12 & 34.3 \\
\hline $\begin{array}{l}\text { Zarvanytsia mountain (outskirts of Zarvanytsia village, } \\
\text { Zolochiv district, Ternopil region) }\end{array}$ & $\begin{array}{l}\text { Brachypodieta pinnati, } \\
\text { Molinetum caerulea }\end{array}$ & 20000 & 1000 & 21 & 2.1 & 121 & 12.1 & 46 & 4.6 & 812 & 81.2 \\
\hline
\end{tabular}


We provide a generalized list of communities with $C$. cirsioides:

Formation Cariceta humilis

Associations: Carex humilis + Bromopsis inermis;

Carex humilis + Thalictrum foetidum;

Carex humilis + Anthericum ramosum.

Formation Bromopsideta inermis

Association: Bromopsis inermis + Carex humilis.

Formation Festuceta valesiacae

Asociations: Festuca valesiaca + Inula ensifolia

Festuca valesiaca + Helictotrichon desertorum;

Formation Festuceta rubrae

Association: Festuca rubra + Elytrigia repens + Filipendula vulgaris.

Formation Anthericeta ramosi

Associations: Anthericum ramosum + Carex humilis;

Anthericum ramosum + Bromopsis inermis;

Anthericum ramosum + Brachypodium pinnatum.

Formation Elytrigieta intermediae

Association: Elytrigia intermedia + Inula ensifolia.

Formation Elytrigieta repentis

Association: Elytrigia repens + Melamphyrum arvense.

Formation Brachypodieta pinnati

Associations: Brachypodium pinnatum + Carex humilis;

Brachypodium pinnatum + Anthericum ramosum;

Brachypodium pinnatum + Festuca valesiaca:

Brachypodium pinnatum + Inula ensifolia;

Brachypodium pinnatum + Molinia caerulea + Elytrigia repens;

Brachypodium pinnatum + Sesleria caerulea;

Brachypodium pinnatum + Poa pratensis;

Brachypodium pinnatum + Elytrigia intermedia.

In the Polissia $C$. cirsioides grows in thinned-out open broad- leaved and mixed forests, and around them.

\section{Discussion}

Carlina cirsioides Klok. was described by Klokov (1954) using a herbarium sample collected by A. H. Rakochy in 1901 from the outskirts of Bilychi village near Kyiv (the sample is stored in the Komarov Botanical Institute of the Russian Academy of Sciences in Saint Petersburg).
According to the first description by Klokov (1954) and his description in "The Flora of USSR" (Klokov, 1962), C. cirsioides is monocarpic, biennial plant, endemic and relic plant of the Ukrainian flora. Its root system is represented by a strong central root which goes $30-40 \mathrm{~cm}$ deep. The stems are singular, around 5-55 cm (up to $1 \mathrm{~m}$ ) long, usually welldeveloped, rarely shortened, erect, regular, spiny-wooly, thin felt-like until bloom, dirty-purple under the indumenta, with one large petiole.The leaves are arranged into basal rosette and are located along the stem, lightgreen, hard, petiolate, with brownish dirty purple, the petiole which is only slightly enlarged at the base and three times shorter than the lamina, with no spines on the margins, elongated-elliptic to elliptic on the outline, of around $11-45 \mathrm{~cm}$ long and $7-15 \mathrm{~cm}$ wide, notably woolly on both sides during bloom, quite densely woolly to sparsely woolly at a young age; there are 4-10 pairs of lateral segments ot leaf lobes, about 10-68 mm long and $6-50 \mathrm{~mm}$ wide, pinnate and partly separated, with elongatedlancete spiky lobes, serrated (together with the apical part) on the margins.

The capitulum is about $4-5 \mathrm{~cm}$ long (with simple inner leaves of the involucre) and about $9-13 \mathrm{~cm}$ in diameter with outward bent horizontal leaves, the capitulum disk (without leaves) is $4.0-7.5 \mathrm{~cm}$ in diameter; the upper leaves which support the capitulum partly resemble the basal and stem ones, up to $20 \mathrm{~cm}$ long and $9 \mathrm{~cm}$ wide, but mostly smaller, with broad petioles and feathery-ramified spines below the middle, transitional in shape and sizes to leaves of the involucre of the outer row; the latter are sessile, with ramified spines on the sides, slightly enlarged or narrowed on the apices, spine-sharpened, in general elongated on the outline, 14 $50 \mathrm{~mm}$ long, 7-15 mm wide, mostly dark brown; their spines are divided into 2-8 parts; the middle leaves are ovoid or narrow lancet, $11-25 \mathrm{~mm}$ long and $2.5-5.0 \mathrm{~mm}$ wide (at the base), thinly sharpened, brownish on the outer side, notably woolly, the broader and shorter of these leaves above the middle have notable dense spines on the sides; the inner leaves are linear or narrow linear, 33-37 mm long and 2-5 mm wide; slightly broadened on the sides above the middle, glossy and yellowish in this region; brownish-dark purple below the middle on the outer side, almost the same on the inner side as above, sharpened at the apices; the coronas are 11$13 \mathrm{~mm}$ long, with with $1.2-1.7 \mathrm{~mm}$ long yellowish teeth. The achenes are oblong, 3.8-6.0 mm long, $1.5-2.0 \mathrm{~mm}$ wide, dark grey, densely hairy, with a circle of up to $2.5 \mathrm{~mm}$ long hairs at the apex, the papus is 14 $17 \mathrm{~mm}$ long and its hairs are stuck together in bundles of 5-7.

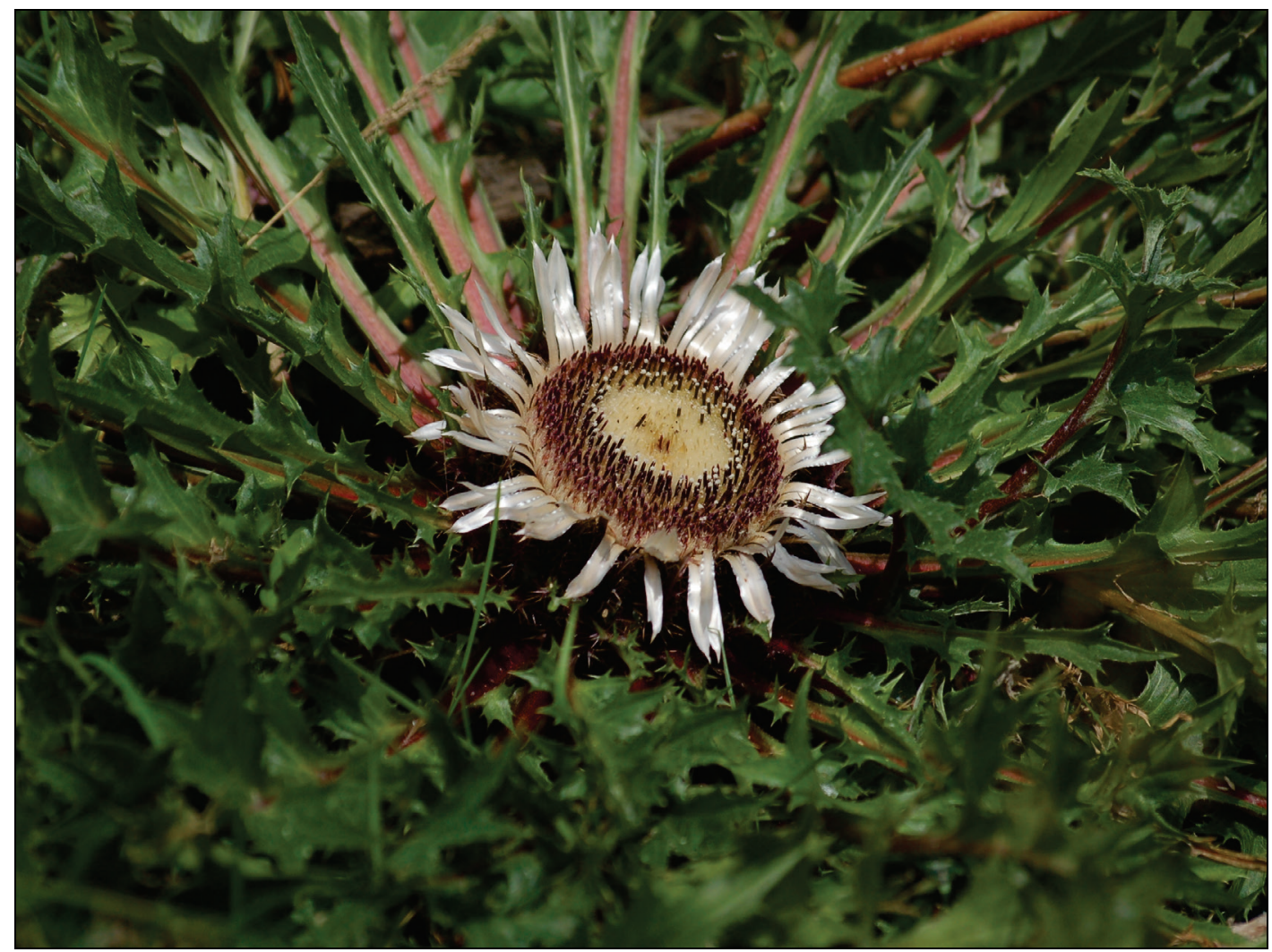

Fig. 3. Carlina acaulis acaulis 


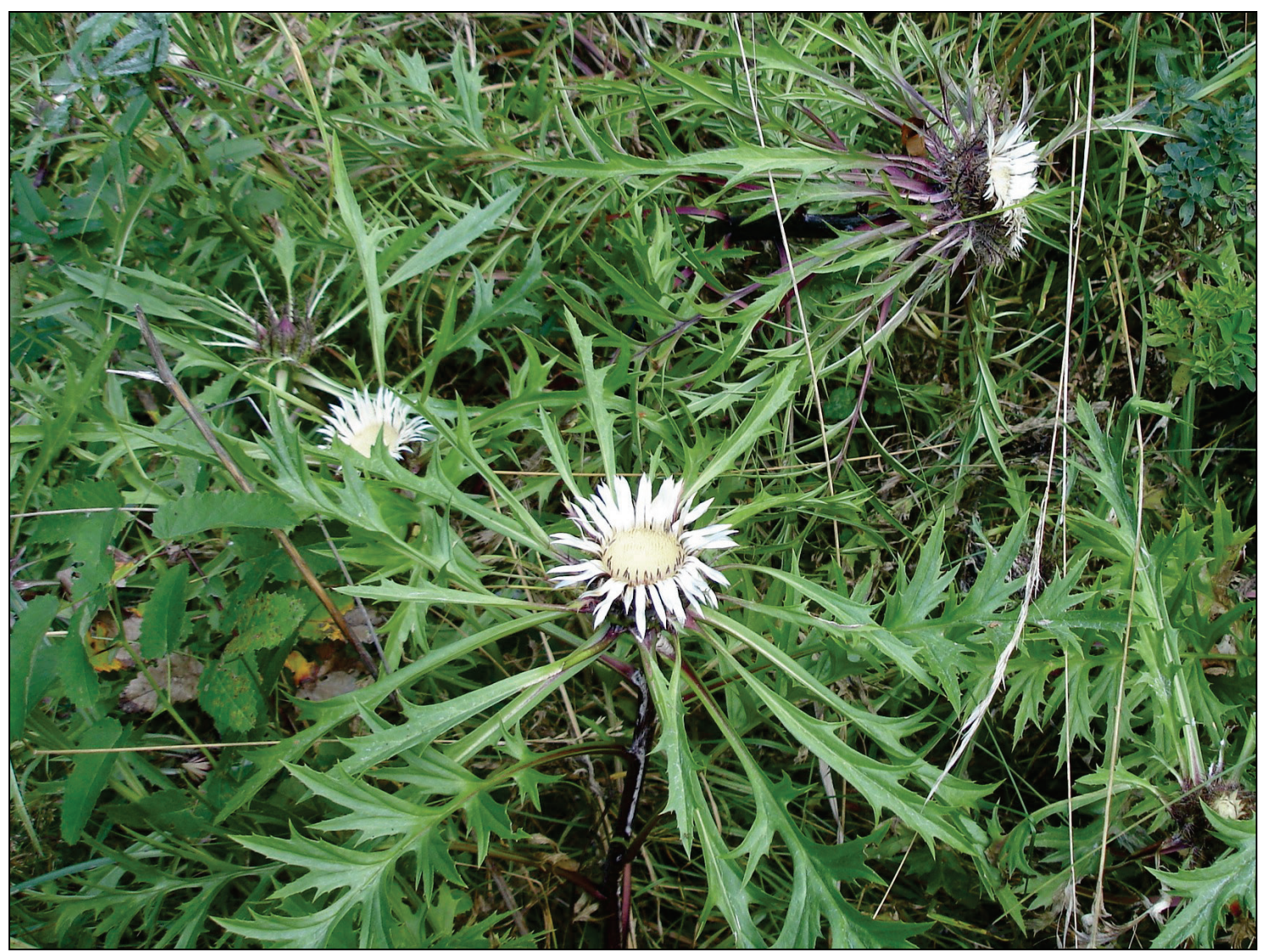

Fig. 4. Carlina cirsioides $(=$ C. acaulis caulescens $)$

Klokov (1954) summarizes the analysis of morphological traits of C. cirsioides as a new species by noting that "our species is notably different from Carlina acaulis L., except for distinct developed stems, other shape of leaves and more distinguished indumenta on them, and also much finer capitula".

Are there enough such small traits to identify a new species? - Obviously not. Therefore, it is not by chance that this taxon has not been identified as a separate in the monographs on Carlina (Meusel \& Kästner, 1994). While not recognizing the species $C$. cirsioides, they identified specimens with distinct stems to subspecies $C$. acaulis ssp. caulescens (Lam.) Schriber et Martens. Unlike the stemless or short-stemmed subspecies $C$. acaulis acaulis (Fig. 3), C. acaulis caulescens (Fig. 4.) is a plant composed of well developed flower-bearing shoots of 20-40 (up to 90) $\mathrm{cm}$ height, with no leaves or with pre-stem leaves. Unlike $C$. acaulis acaulis, distributed in the mountains of Europe (Pyrenees, Apennine Mountains, Balkans, Alps, the Carpathias), C. acaulis caulescens grows not only in mountains, but also in the lowlands of Europe. Therefore, in the Hercynian massifs of Europe, this subspecies is distributed in the Bourgogne Upland, the Rhenish Massif, Thuringian Forest (Meusel \& Kästner, 1994).

The author of description of Carlina species in "Flora Europaea" (Webb, 1976) also distinguishes two subspecies of $C$. acaulis. C. acaulis caulescens in sense of the monographs on the genus Carlina corresponds to subspecies $C$. acaulis simplex (Waldst. et Kit) Nyman. with ramified or regular stems. He did not recognize the species independence of Carlina cirsioides.

Hegi (1987) distinguishes two subspecies of $C$. acaulis, and within subspecies $C$. acaulis acaulis, he distinguishes form var. caulescens Lam., which is distinct by developed stems of up to $30 \mathrm{~cm}$ long and the rosette of leaves located around the inflorescence. Another subspecies of this species, Carlina acaulis aygreta Waldst. et Kit $(=$ C. acaulis simplex (Waldst. et Kit), has developed stems and no rosette around the inflorescence.

In the flora of Romania (Nyarady, 1964), three forms of C. acaulis are described: typical var. typical Beek - stemless or short-stemmed plant with a rosette of leaves; var. alpine Beek. 1.c. (var. caulifera Bauneg.) with developed 10-40 (50) $\mathrm{cm}$ stems and rosette of leaves around the capitulum; var. aqgregata W. et K. - with developed stems and singular leaves on them. In Poland, C. acaulis is common in mountain regions (Carpathians, Sudetes), and also in Małopolska Upland. In other lowland territories (Wielkopolska, Kujawy, Masurian Lake district, Pomerania) it occurs rarely. At the same time the populations are represented mostly by subspecies C. acaulis caulescens (Wasilowska \& Wolkowski, 2009).

The review we provided indicates that $C$. acaulis is a complex syngameon composed of mostly highland stemless or short-stemmed subspecies $C$. acaulis acaulis and mostly lowland subspecies $C$. acaulis caulescens. Morphological traits of the species $C$. cirsioides described by Klokov completely coincide with the traits of the latter subspecies. The analysis of herbarium samples of $C$. cirsioides kept in the Herbarium of the M. G. Kholodny Institute of Botany of the National Academy of Sciences of Ukraine showed that there are plants both having welldeveloped stems with rosettes of leaves around the inflorescences or without them, and stemless plants.

The folders under the name "Carlina acaulis" in the Herbarium of the M. G. Kholodny Institute of Botany of the National Academy of Sciences of Ukraine, along with stemless and short-stemmed plants also contain plants with well-developed stems which morphologically do not differ from the samples stored in the folders titled " $C$. cirsioides". The difference between them is in geographical distribution. The first were collected in the Carpathians, whereas the latter come from the plains part of Ukraine. Therefore, a logical question is why highland plants are identified to C. acaulis, while the lowland plants to $C$. cirsioides. It would be worth rejecting the species name $C$. cirsioides and use the priority name $C$. acaulis for plants from the entire territory of Ukraine. By the way, all the samples of the plants initially collected in the lowlands, starting from the collections of Montrezor (1898), were identified as C. acaulis caulescens, as documented on the labels. They were transferred to $C$. cirsioides after revision by Klokov (1954), as indicated in his nota critica. Because the plants from the plains territory of Ukraine occur only under the name $C$. cirsioides in all the editions of the Red Book of Ukraine (Didukh, 2009) and the International Red Lists (European..., 1991), it is acceptable to use this name as $C$. acaulis synonym. Klokov $(1954 ; 1962)$ describing the new species $C$. cirsioides, identifies it to biennial monocarpic plants. Fol- 
lowing Klokov, this species was related to monocarpic by Shishkin \& Bobrov (1962), Belousova et al. (1979) and other authors. Based on the observations on the plant in the conditions of nature and cultivation, Zelenchuk (1987) came to a conclusion that $C$. cirsioides is perennial polycarpic plant. Our multi-years monitoring of growth and development of this species in the natural and cultivation conditions confirms this point of view.

The data provided above do not allow the population of the lowland part of Ukraine to be identified as a separate species $C$. cirsioides. According to all morphological traits it is $C$. acaulis. Therefore, the statement of Klokov (1962) that $C$. cirsioides is a separate species, endemic and relic plant of the flora of Ukraine is erroneous. Neither has the relic nature of it been confirmed by phytogeographical data. There are no reliccharacteristic types of disjunct distribution in the range of this "species". The Ukrainian lowland populations adjoin directly to the Carpathian part of the range of $C$. acaulis and plains populations of this species in Poland. In general, $C$. acaulis is a Central European species, the range of which mostly includes mountain regions of Europe (Pyrenees, Alps, Apennine Mountains, Jura Mountains, Balcans, Carpathias and the neighbouring plains of the Hercynian massifs of Europe (Bourgogne Upland, the Rhenish Massif, Thuringian Forest), Poland (Pomerania, Masurian Lake district, Wielkopolska, Kujawy, Małopolska Upland) and Ukraine (Vohlynian-Podolian Upland and the Polesian Lowland).

In Ukraine C. acaulis is chiefly distributed in the Carpathians (Fig. 5), and plains (Fig. 1), this species grows near the north-east border of its range and is quite rare. Its range border runs along the edge of the Polesian Lowland near Derazhne villige of Kostopil district of Rivne region, Zhytomyr, Kyiv and Brovary, from where it makes a turn toward the south, passing near Berdychiv, Vinnytsia, Khmelnytsky, and Pidvolochysk.

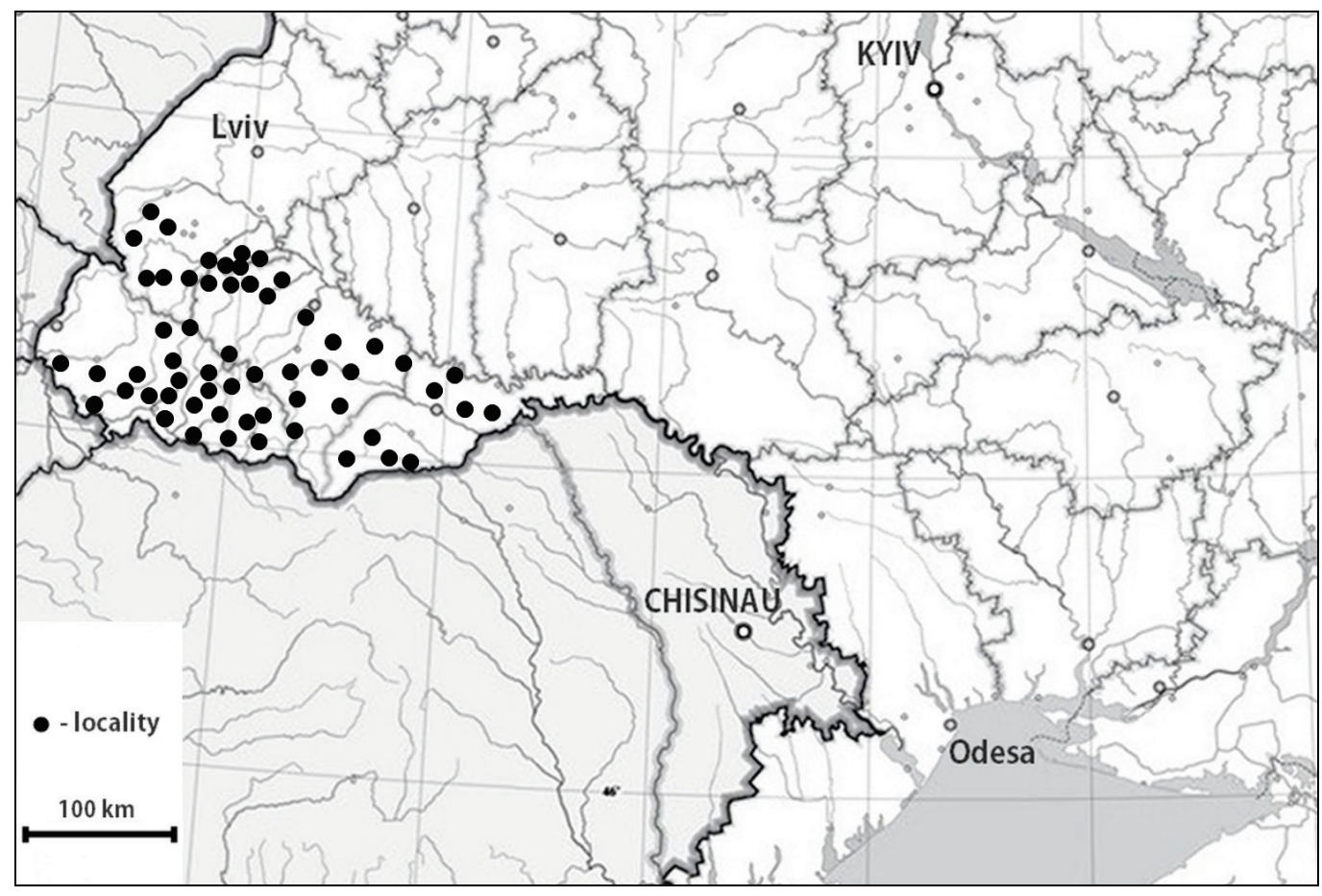

Fig. 5. Geographical distribution of Carlina acaulis acaulis in Ukrainian Carpathians

According to the data of Klokov (1962), the new species of the Carlina genus which he described, grows in thinned-out forests, dry meadows and steppe slopes. Our detailed analysis of it habitat revealed that in the Podoilina Upland it is confined mostly to meadow steppes on the slopes of the buttes of south, west and east exposition, where it grows in calciumrich soils (rendzinas).

The species is a component of formations of Cariceta humilis, Brachypodieta pinnati, Bromopsideta inermis, Festuceta valesiacae, Festuceta rubrae, Anthericeta ramosi, Elytrigieta intermediae, зокрема асоціацій Carex humilis + Bromopsis inermis, Carex humilis + Thalictrum foetidum, Carex humilis + Anthericum ramosum, Festuca valesiaca + Inula ensifolia, Festuca valesiaca + Helictotrichon desertorum, Festuca rub$\mathrm{ra}+$ Elytrigia repens + Filipendula vulgaris, Anthericum ramosum + Carex humilis, Anthericum ramosum + Bromopsis inermis, Anthericum ramosum + Brachypodium pinnatum, Elytrigia intermedia + Inula ensifolia, Brachypodium pinnatum + Carex humilis, Brachypodium pinnatum + Anthericum ramosum, Brachypodium pinnatum + Festuca valesiaca, Brachypodium pinnatum + Inula ensifolia, Brachypodium pinnatum + Molinia caerulea + Elytrigia repens, Brachypodium pinnatum + Sesleria caerulea, Brachypodium pinnatum + Poa pratensis, Brachypodium pinnatum + Elytrigia intermedia. Much rarer occurrence of $C$. cirsioides is noted in ecotones among the forest and meadow vegetation in forest open areas. In the southernmost part of the Polesian Lowland, C. acaulis grows in light pine and mixed forests.

Therefore, in the plains of Ukraine, C. acaulis is mostly a component of steppe communities of Festuco-Brometea class, and much rarer the forest communities of Erico-Pinetea class and meadow-forest ecotones.
Mountain habitats of $C$. acaulis significantly differ from the plains ones. In the Carpathians, $C$. acaulis is a component of mountain meadows, confined to warm slopes covered with dense peat formations of matgrass Nardus stricta, wood small-reed Calamagrostis epigejos and bonfire grasses, reaching the altitude of 2,000 $\mathrm{m}$ (Malynovskyi, 1980).

Simular habitats are in Alps, where it grows in subalpine meadow with domination of Bromus erectus Huds, Nardus stricta L., Festuca valesiaca Gaudin (Hegi, 1987).

In Sudets, $C$. acaulis grows in mountain pastures and is a component of of the plant community Molinio-Arrhenathereta class (Nadolna, 2013).

In the lowland regions of the Central Europe, the habitats of C. acaulis are very different from the mountain ones. There, the species is confined mostly to xerophilous herbaceous communities on calcium-rich soils. Such communities are reported for the Vosges, Schwarzwald, Bavarian Forest, Swabian Alb, Swabian-Bavarian Plateaau (Meusel \& Kastner, 1994).

In North-West Germany, C. acaulis is a component of the xerotherm calciphilous herbaceous communities with domination of Brachypodium pinnatum (L.) P. Beauv, Festuca valesiaca, Bromus erectus Huds., and participation of Cirsium acaule, Carlina vulgaris L., Gentianella ciliata. Together with Brachypodium pinnatum (L.) P. Beauv, C. acaulis grows in the Württemberg Lowland (Ellenberg, 2009).

In the Thuringian Basin, C. acaulis grows on calcium-rich soils and is a component of communities formed by Bromus erectusus Huds., Sesleria caerulea (L.) Ard, Festuca ovina L. with participation of Pulsatilla vulgaris Mill., Gentiana cruciata L., Bupleurum falcatum, Laserpitium latifolium L. (Hegi, 1987). In the lowland regions of Poland in the valleys 
of the Vistula, the Lower Odra, Małopolska Upland (Kielce-Sandomierz Upland), Lublin Upland Kraków Upland, locations with $C$. acaulis include steep slopes of the river valleys, outcrops of rocks in xerothermic meadows. In the North-East Poland, $C$. acaulis grows in pine forests (Wasilowska \& Wolkowski, 2009).

Comparison of ecological-coenotic conditions of habitats of C. acaulis revealed significant differences between plains and mountain ecotopes. In the Carpathians and Alps, this species is a component of mountain meadows, while in the plains regions of Europe it is confined mostly to meadow steppes in the east of the range and xerothermal herbaceous communities in the western part. These communities $\mathrm{s}$ are floristically close and confined to calcium-rich soils. Forest communities with $C$. acaulis in the Polesian Lowland are close to the adjacent ecotopes of the North-East Poland. Thus, ecological-coenotic habitat conditions of the plains part of Ukraine are not specific, and rather are typical for all the plains part of the range of $C$. acaulis.

In general, the data on morphology, chorology and phytocoenology do not allow us to consider $C$. cirsioides described by Klokov a separate species, endemic and relic plant of the Flora of Ukraine. Plains localities of this "species" in Ukraine may conditionally be considered geographic population of $C$. acaulis. Identification of this population to C.acaulis does not in any way reduce its phytosozoological value at all, the reason being is that xerothermal meadow communities involving $C$. acaulis are rare in plains throughout Europe and this species has been included in the lists of species which need protection in France and Poland (Boron et al., 2019; Strzemski et al., 2019).

Analysis of the abundance of the population of $C$. acaulis in the plain part of its range in Ukraine showed that near the eastern border of the range this species is extremely rare. A count of the number of specimens in populations of $C$. acaulis in the Podolian Upland (Table) revealed that they comprise 3 to 2,000 individuals. The population was the lowest on the Makitra Mountain (Lviv region) - only three specimens. In five of 14 surveyed populations, there are several dozens of specimens -25 to 90 , or several hundreds of specimens -135 to 630 specimens (Table). And only in two local populations - on the Chortova Mountain in Ivano-Frankivsk region and the Zarvanytsia Mountain in Ternopil region, did the population accouns for around 1,000 specimens in each (Table). Therefore, the abundance of the populations is extremely low. Average density of populations equaled $3-5$ specimens $/ \mathrm{m}^{2}$, maximal -20 specimens $/ \mathrm{m}^{2}$.

The data we obtained correlate with the materials of accounts of populations of this species conducted in the Burshtyn Opillia (Ivano-Frankivsk region) in 2009-2011 by Dmytrash, Shumska (2011). The number of specimens from nine populations they surveyed was 25 to 5,000 specimens. Outside the Podolian Upland, on the border of the Polesian Lowland, only singular individuals of $C$. acaulis were found.

Carlina cirsioides $(=C$. acaulis) within Vohlynia-Podillia was noted by high parameters of seed productivity. According to the data of Zelenchuk (1987), the actual seed productivity of this species accounted for 270 seeds per individual, the seed yield from area of $25 \mathrm{~m}^{2}$ was 8,800 seeds, and the seed germination rate equaled $70-80 \%$.

In the conditions of good seeding of the habitats, dense herbaceous cover with dominance of grasses is an obstruction to seeds, preventing them from entering the mineral part of soil. Therefore, in germinationfavourable conditions, only a small portion of seeds is introduced to the soil. The parameter of dying of seddlings is fairly high, related to deficiency of moisture in the soil during summer. A total of $42-50 \%$ seddlings die (Zelenchuk \& Zelenchuk, 1987).

Moderate cattle grazing (animals break up the turf with their hooves) would obviously have helped the seeds to enter the mineral part of soil, where conditions for growth and development of sprouts are optimum. Thus, grazing cattle would provide the conditions of intensive replenishment of populations with new generations of individuals.

Significant damage to populations of $C$. acaulis near the Eastern border of the range is caused by preparation of medicinal raw materials from its herbs. This species is used in both official and folk medicine, especially in Germany and Poland (Link et al., 2014; Strzemski et al., 2019). In general, populations of $C$. acaulis near the eastern border of its range in Volhynia-Podillia are mainly homeostatic (Table), indicating that coenotypical conditions of meadow steppes which cover the slopes of the buttes meet the ecological needs of $C$. acaulis. Beyond the borders of the existing localities, there is not a sufficient amount of ecotopes favourable for the development of invasive populations, though the seeds there are easily distributed to large distances. In Vohlyni-Podilla, there was found one invasive population on the Makitra Mountain (Lviv region), consisting of only three specimens. As mentioned above, in the Polesian Lowland, only single individuals of this species occur.

Populations of $C$. cirsioides $(=C$. acaulis) have sufficient protection in the plains of Ukraine. They are protected in the Halytsky National Nature Park (Ivano-Frankivsk region), in Medobory Nature Reserve (Ternopil region), Botanical monuments of the National Importance: Lysa Hora Mountain and Sypuha Mountain (Lviv region), Chortova and Kasova Mountains (Ivano-Frankivsk region), Botanical Reserve of Local Significance Mohyla Mountain and the Kurylyha Mountain (Ternopil region), in the Adamove Zaimysko Tract (Khemelnytsky region).

Following our scientific recommendations, a botanical reserve Kurylyha Mountain was created in Ternopil region. Taking into account the high phytosozological value of $C$. acaulis near the eastern border of the range, in the future all populations of this species in Volhynia-Podillia and Polissia should be taken under protection.

\section{Conclusions}

Carlina cirsioides Klokov (Asteraceae), a well-known endemic plant of the Flora of Ukraine, is actually not an endemic of our Flora. Comparative-morphological and geographical analyses revealed that the populations of this "species" are identified to Carlina acaulis L. and have no significant differences from the populations in the plains regions of Central Europe which belong to subspecies $C$. acaulis caulescens. Diagnostic traits according to which $C$. cirsioides was described are so insufficient that they provide no reasons for distinguishing it as a species different from C. acaulis.

Identification of populations from Volhynia-Podillia and Polissia to relic plants of the Flora of Ukraine is erroneous because they are not separate and directly adjoin to the Carpathian part of the range of $C$. acaulis and its populations in Poland.

Ecological-coenotic conditions of habitats of $C$. acaulis in the plains of Ukraine are different from the Carpathian ecotopes and close to plains regions of Central Europe. Meadow steppe formations of Brachypodieta pinnati, Bromopsideta inermis, Cariceta humilis, Festuceta valesiacae, including C. acaulis, in Vohlynia-Podillia, according to ecologicalcoenotic conditions and floristic composition are close to xerotherm herbaceous communities of Central Europe, and open pine and mixed forests are habitats of $C$. acaulis in Ukraine and North-East Poland.

Analysis of age structure of populations of $C$. acaulis in the plains of Ukraine revealed that most of them are homeostatic with right-sided spectra of ontogenetic states. A minimum was seen in juvenile and immature specimens, which is related to obstructions for seeds to enter the mineral soil due to the high level of development peat and significant rate of death of sprouts under the dense herbaceous layer. The share of invasive populations is small due to absence of favourable ecological-coenotic conditions outside the existing localities of $C$. acaulis.

Despite the removal of separate species status of the population in the plains of Ukraine due to the correction of their identification from endemic species C. cirsioides to the broadly-distributed European species $C$. acaulis, their phytosozoological importance remained unchanged.

C. acaulis is rare in the Ukrainian plains because of its narrow ecologic-coenotic amplitude and negative anthropogenic impact on habitats and populations (forestation of slopes, collection of plants as medicinal raw material and bouquets). To protect the gene fund of $C$. acaulis, all populations of $C$. acaulis near the eastern border of the range of the species should be taken under protection.

\section{References}

Belousova, L. S., Denisova, L. V., \& Nikitina, S. V. (1979). Redkie rasteniya SSSR [Rare species of plants of the USSR]. Lesnaya Promyishlenost, Moskow (in Russian). 
Berg, C., Abdank, A., Isermann, M., Jansen, F., Timmermann, T., \& Dengler, J. (2014). Red lists and conservation prioritization of plant communities - a methodological framework. Applied Vegetation Science, 17, 504-515.

Boroń, M., Ociepińska, M., Żeber-Dzikowska, I., Gworek, B., Kondzielski I., \& Chmielewski, J. (2019). Xerothermic pavements - a meadow biodiversity richness. Jaworzno case study, Environmental Protection and Natural Resources, 30(3), 29-34.

Bowman, M., Davies, P., \& Redgwell, C. (2010). The convention on the conservation of European wildlife and natural habitats. In: Lyster's International Wildlife Law. Cambridge University Press, Cambridge. Pp. 297-345.

Brigham, C. A., \& Schwartz, M. W. (2003). Population viability in plants: Conservation, management, and modeling of rare plants. Springer-Verlag Berlin Heidelberg, New York.

Corlett, R. T. (2016). Plant diversity in a changing world: Status, trends, and conservation needs. Plant Diversity, 38(10-16), 10-15.

Didukh, Y. P. (2009). Chervona knyha Ukrainy. Roslynnyi svit [The Red Data Book of Ukraine. Plant world]. Hlobalkonsaltynh, Kyiv (in Ukrainian).

Diekson, B. (2013). Endangered species threatened convention. The past, present and future of CITES, the convention on international trade in endangered species of wild fauna and flora. London.

Dmytrash, I. I., \& Shumska, N. V. (2011). Poshyrennia ta ekoloho-tsenotychni osoblyvosti Carlina cirsioides Klokov i Carlina onopordifolia Besser. ex Szafer, Kulcz. et Pawl. na Burshtynskomu Opilli [Distribution and ecological and coenotical peculiarities of Carlina cirsioides Klokov and Carlina onopordifolia Besser ex Szafer, Kulcz. et Pawl. on the Burshtyn Opillia]. In: Theoretical and practical aspects of florology and phytososology. Naukova Dumka, Kyiv. Pp. 77-81 (in Ukrainian).

Ellenberg, H. (2009). Vegetation ecology of Central Europe. Cambridge University Press, Cambridge.

European List of Globally Threatened Animals and Plants (1991). United Nations, New Jork.

Falk, D. A., \& Holsinger, K. E. (1991). Genetics and conservation of rare plants. Oxford University Press, New York.

Hegi, G. (1987). Illustrierte Flora von Mitteleuropa, Band 6, Heffte 2, Teil 4. Pau Parey, Berlin.

Heywood, V. H. (2009). A global strategy for the conservation of plant diversity. Grana, 34, 363-366.

Klokov, M. V. (1954). Novyie ukrainskie slojnotcvetnyie [New Ukrainian Compositae]. In: Botanical materials of Herbarium of V. L. Komarov Botanical Institute Academy of Sciences of USSR. Leningrad. Pp. 355-368 (in Russian).

Klokov, M. V. (1962). Rid vidkasnyk - Carlina L. [Genus Carlina L.]. In: Flora of Ukrainian SSR. Vydavnyctvo AN Ukrajins'koji RSR, Kyiv. Vol. 11. Pp. 419 431 (in Ukrainian).

Laguna, E., Fos, S., Jiménez, J., \& Volis, S. (2016). Role of micro-reserves in conservation of endemic, rare and endangered plants of the Valencian region (Eastern Spain). Israel Journal of Plant Sciences, 63(4), 320-332.

Link, P., Roth, K., \& Wink, M. (2014). Carlina acaulis has antioxidant effects and ameliorates beta-amyloid toxicity in a C. elegans model. Alzheimer's and Dementia, 10(45), 465.

Luzuriaga, A. L., Escudero, A., Albert, M. J., \& Gimenez-Benavides, L. (2006). Population structure effect on reproduction of a rare plant: beyond population size effect. Canadian Journal of Botany, 84(9), 1371-1379.

Malynovskyi, K. A. (1980). Roslynnist vysokohiria Ukrainskykh Karpat [Vegetation of the highlands of the Ukrainian Carpathians]. Naukova Dumka, Kyiv (in Ukrainian).
Melnyk, V. (2011). Carlina onopordifolia. The IUCN Red List of Threatened Species

Melnyk, V. I., \& Parubok, M. I. (2004). Horytsvit vesnianyi (Adonis vernalis L.) v Ukrajini [Spring adonis (Adonis vernalis L.) in Ukraine]. Fitosotsiotsentr, Kyiv (in Ukrainian).

Meusel, H., \& Kästner, A. (1994). Lebensgeschichte der Gold and Silberdisteln. In Monographie der Mediterran - Mitteleuropaischen Compositen - Gattung Carlina. Vol. 2. Springer-Verlag Wien, New York, Wien.

Montrezor, V. V. (1898). Spisok rasteniy, sobrannyih v Kievskom uchebnom okruge $\mathrm{v}$ posledniy 25-letniy period vremeni [List of plants collected in the Kiev educational district in the last 25-year period of time]. Zapiski Kievskogo Obschestva Estestvoispyitateley [The Notes of Kiev Society of Naturalists], 15(2), 675-707 (in Russian)

Motyka, J. (1947). Rozmieszczenie i ekologia roslin naczyniowych na polnocnej krawedzi Zachodniego Podola [Distribution and ecology of vascular plants on the northem border of West Podolia]. Universitet Mari Curie-Sklodowskiej, Lublin (in Polish)

Nadolna, L. (2013). The importance of pastures in the Sudeten, in the protection of floristic diversity and utility value. Ecological Engineering and Environmental Technology, 33, 77-85.

Nyarady, E. I. (1964). Fam. 107. Compositae Adans. Flora Republicii Populare Romine. Editura Academici Republicii Populare Romine, Bucuresti. Pp. 924 957 (in Romanian).

Quinones-Perez, C. Z., Simental-Rodriguez, S. L., Saenz-Romero, C., Jaramillo-Correa, J. P., \& Wehenkel, C. (2014). Stapial genetic structure in the very rare and species-rich Picea chihuahuana tree community (Mexico). Silvae Genetica, 63(4), 149-159.

Rabotnov, T. A. (1978). Fytotsenolohyia [Phytocenology]. Edition of Moscow University, Moscow (in Russian).

Shishkin, B. K., \& Bobrov, E. G. (1962). Rod Carlina L. [Genus Carlina L.]. In: Flora SSSR. Izdatel'stvo AN SSSR, Moscow. Vol. 27. Pp. 77-87 (in Russian).

Strzemski, M., Wójciak-Kosior, M., Sowa, I., Załuski, D., \& Verpoorte, R. (2019). Historical and traditional medical applications of Carlina acaulis L. - A critical ethnopharmacological review. Joumal of Ethnopharmacology, 239, 1-8.

Volis, S. (2016). How to conserve threatened Chinese plant species with extremely small populations? Plant Diversity, 38(1), 45-52.

Wahrmund, U., Heklau, H., Röser, M., Kästner, A., Vitek, E., Ehrendorfer, F., \& Von Hagen, K. (2010). A molecular phylogeny reveals frequent changes of growth form in Carlina (Asteraceae). Taxon, 59(2), 367-378.

Wasilowska, E., \& Wolkowski, D. (2009). New localities of Carlina acaulis (Asteraceae) in North-Eastern Poland. Fragmenta Floristica et Geobotanica Polonica, 16(1), 59-64.

Webb, D. A. (1976). Carlina L. In: Flora Europaea. Cambridge University Press, Cambridge. Vol. 4. Pp. 208-211.

Zelenchuk, T. K., \& Zelenchuk, A. T. (1987). Nasinnieve rozmnozhennia ta ponovlennia Carlina cirsioides Klok na Zakhidnomu Podilli [Seed propagation and replenishment of Carlina cirsioides Klok in Western Podillya]. Ukrainian Botanical Journal, 44(2), 17-20 (in Ukrainian).

Zelenchuk, T. K., \& Zelenchuk, A. T. (1996). Ontomorfogenez i jiznennaya form Carlina cirsioides Klok v usloviyah Zapadnoy Podolii [Ontomorphogenesis and life form of Carlina cirsioides Klok in the conditions of Western Podolia] Lviv University Press, Lviv (in Russian). 